\title{
TOCOPHEROL COMPOSITION AND ANTIOXIDANT ACTIVITY OF SPANISH WILD VEGETABLES
}

Patricia Morales ${ }^{1,2}$, Ana Maria Carvalho ${ }^{1}, M^{\text {a }}$ Cortes Sánchez-Mata ${ }^{3}$, Montaña Cámara $^{3}$, María Molina ${ }^{4}$, Isabel C.F.R. Ferreira ${ }^{1, *}$

${ }^{1}$ Centro de Investigação de Montanha, ESA, Instituto Politécnico de Bragança, Campus de Santa Apolónia, Apartado 1172, 5301-854 Bragança, Portugal.

${ }^{2}$ Dpto. de Ciencias de la Salud, Universidad Internacional Valenciana (VIU). Calle José Pradas Gallen, s/n 2ºiso. E-12006 Castellón de la Plana, Spain.

${ }^{3}$ Dpto. Nutrición y Bromatología II. Facultad de Farmacia. Universidad Complutense de Madrid (UCM). Pza Ramón y Cajal, s/n. E-28040 Madrid, Spain.

${ }^{4}$ Instituto Madrileño de Investigación y Desarrollo Rural, Agrario y Alimentario (IMIDRA). Finca "El Encín", Apartado 127. E-28800 Alcalá de Henares, Spain.

*Author to whom correspondence should be addressed (e-mail: iferreira@ipb.pt; telephone +351-273-303219; fax +351-273-325405). 


\begin{abstract}
Traditional use of noncultivated vegetables has decreased with the development of agriculture and global supply chains. However, some species are still consumed as part of our traditional Mediterranean diet. Plants are among the most important sources of natural antioxidants for retarding lipid oxidative rancidity in foods or for pharmaceutical applications against chronic diseases related to free radicals production. The present study reports tocopherols composition and antioxidant activity of eight wild greens traditionally used in Spain. According to the edible part consumed, two groups were differentiated. Leafy vegetables whose young stems with leaves are consumed (Apium nodiflorum (L.) Lag., Foeniculum vulgare Mill., Montia fontana L. and Silene vulgaris (Moench) Garcke), and wild asparagus whose young shoots with leaf buds scarcely developed are eaten (Asparagus acutifolius L., Bryonia dioica Jacq., Humulus lupulus L. and Tamus communis L.). Among the leafy vegetables, Silene vulgaris and Apium nodiflorum presented the highest antioxidant capacity and antioxidants contents. Among the wild asparagus, the highest antioxidant capacity was obtained in Humulus lupulus.
\end{abstract}

Keywords: Antioxidant activity; Tocopherols; Wild vegetables 


\section{Introduction}

Oxidative stress causes the production of highly reactive oxygen species (ROS), such as superoxide and hydroxyl radicals, and other species as hydrogen peroxide and singlet oxygen, originated either by exogenous or endogenous factors (Ferreira et al. 2009). When the generation of ROS exceeds the antioxidant capacity of the organism, cellular and metabolic injury might occur, leading to a variety of physiopathological processes (Yang et al. 2008). In fact, the uncontrolled production of free radicals has been related to more than one hundred diseases including cardiovascular diseases (Shah and Channon 2004), neurological disorders (Moreira et al. 2008), and several kinds of cancer (Valko et al. 2006).

Plant foods are rich sources of bioactive compounds, which have been found to possess a great variety of biological activities including antioxidant potential. Epidemiological studies have consistently shown that the consumption of fruits and vegetables is associated with reduced risk of chronic and neurodegenerative diseases, probably due to the presence of antioxidants (as phenolic compounds and tocopherols) that are involved in the delay or prevention of oxidative reactions (Craig 1999; Gerber et al. 2002; Di Matteo and Esposito 2003).

As stated by Burton and Traber (1990), Vitamin E is the term used to designate a family of chemically related compounds, namely tocopherols and tocotrienols, with a chromanol head and an isoprene side chain. Tocopherols $(\alpha, \beta, \gamma$ and $\delta$-tocopherol) act as antioxidants by their capacity to scavenge lipid peroxyl radicals of unsaturated lipid molecules, preventing propagation of lipid peroxidation, mainly in polyunsaturated fatty acids (PUFAs). The major isoform of vitamin E present in plant tissues is $\alpha$-tocopherol. Moreover, it has been considered the most active form in humans due to a preferential 
absorption and distribution of this compound in the human body (Caretto et al. 2009). Due to its role as free radicals scavenger, vitamin $\mathrm{E}$ is also believed to protect against degenerative processes, such as cancer and cardiovascular diseases (Burton and Traber 1990; Kamal-Eldin and Appelqvist 1996; Schwenke 2002).

Wild vegetables have been previously reported as natural sources of phenolic compounds, mainly flavonoids. Natural phenolic compounds are accumulated as endproducts from the shikimate and acetate pathways and can range from relatively simple molecules (phenolic acids, phenylpropanoids, flavonoids) to highly polymerised compounds (lignins, melanins, tannins), being flavonoids the most common and widely distributed sub-group (Bravo 1998). The antioxidant properties of phenolic compounds are well known. They play a vital role in the stability of food products, as well as in the antioxidative defense mechanisms of biological systems (Nijveldt et al. 2001).

As in other parts of the world, wild vegetables have played an important nutritional role in the Iberian Peninsula. The consumption of vegetables often include various wild greens traditionally collected throughout the countries (Spain and Portugal) and consumed in different ways as a part of the Mediterranean gastronomy. Particularly, Asparagus acutifolius L., Humulus lupulus L., Bryonia dioica Jacq., Tamus communis L. and Silene vulgaris (Moench) Garcke are traditionally consumed cooked, whereas Apium nodiflorum (L.) Lag., Foeniculum vulgare Mill., and Montia fontana L. are normally consumed fresh, mainly in salads (Tardío et al. 2005; Tardío et al. 2006; Carvalho 2010; Tardío 2010).

The presence of toxic compounds has been described in some fresh parts of two of the species included in our study. Saponins have been mentioned in Tamus communis (Hadad Chi and Moradi 2005) and triterpene glycosides and some ribosome inactivating proteins in Bryonia dioica (Biglino and Nano 1965, Siegall et. al 1994). However, 
young shoots with leaves of these species are the least toxic parts of these plants. Toxic principles are more abundant in other plant organs, as fruits and subterranean parts. Moreover, they have been traditionally consumed after a cooking process, which destroy the toxic principles (Couplan 1990; Lin et al. 2006).

The aim of the present study is to provide complete data of tocopherols composition and antioxidant activity of eight Spanish wild vegetables in order to find natural antioxidants suitable to help in the protection of the human organisms against oxidative stress damage. Moreover, as far as we know this is the first report on tocopherols composition of some species as Apium nodiflorum, Montia fontana and Humulus lupulus.

\section{Material and methods}

Plant material

Eight different species of wild vegetables traditionally used in Spain were selected for the analysis. These species were classified in two groups that differ in the edible part consumed. The first group of leafy vegetables, whose edible parts are young stems with developed leaves, is composed by Apium nodiflorum (L.) Lag., Foeniculum vulgare Mill., Montia fontana L. and Silene vulgaris (Moench) Garcke. The second one was the group of "wild asparagus" (it should be remembered that asparagus means "young shoot'” in Latin), with Asparagus acutifolius L., Bryonia dioica Jacq., Humulus lupulus L. and Tamus communis L., whose young shoots with the leaf buds scarcely developed are consumed.

Fieldwork was carried out during 2007-2009 in two wild populations of each species located in Central Spain (see Table 1). In general, each species was collected during 
two consecutive years (2007 and 2008, or 2008 and 2009). Therefore, at least four independent samples were collected per species. The locations were selected in the different habitat where the species occur, i.e., human disturbed habitats (Foeniculum vulgare, Silene vulgaris), uncultivated lands (Asparagus acutifolius, Bryonia dioica, Humulus lupulus and Tamus communis) or streams (Apium nodiflorum and Montia fontana). According to previous ethnobotanical surveys (Tardío et al. 2006), all the species were harvested considering the local collectors' criteria about the part of the plant used and the optimum gathering period. Harvesting took place in spring time, from the middle of March to late May, when the edible parts are still tender (Table 1). Every sample contained plant material from at least 25 separate plants randomly selected. Samples were freeze-dried and subsequently mixed to obtain a representative sample of the geographical and environmental variability considered from the four independent samples of each species.

Standards and reagents

Tocopherol standards $(\alpha, \beta, \gamma$ and $\delta)$, trolox and gallic acid were purchased from Sigma (St. Louis, MO, USA). Racemic tocol, $50 \mathrm{mg} / \mathrm{ml}$, was purchased from Matreya (PA, USA). The 2,2-diphenyl-1-picrylhydrazyl (DPPH) was obtained from Alfa Aesar (Ward Hill, MA, USA). All other chemicals were obtained from Sigma Chemical Co. (St. Louis, MO, USA). The eluents n-hexane $95 \%$ and ethyl acetate $99.98 \%$ were of HPLC grade from Lab-Scan (Lisbon, Portugal). Methanol was of analytical grade purity and supplied by Pronalab (Lisbon, Portugal). Water was treated in a Milli-Q water purification system (TGI Pure Water Systems, USA).

Analysis of tocopherols composition 
Tocopherols content was determined following the procedure previously optimised and described by Barros et al. (2010). BHT (butylhydroxytoluene) solution in hexane (10 $\mathrm{mg} / \mathrm{ml} ; 100 \mu \mathrm{l}$ ) and internal standard (IS) solution in hexane (tocol; $2.0 \mu \mathrm{g} / \mathrm{ml} ; 250 \mu \mathrm{l}$ ) were added to the sample prior to the extraction procedure. Samples $(500 \mathrm{mg})$ were homogenised with methanol $(4 \mathrm{ml})$ by vortex mixing $(1 \mathrm{~min})$. Subsequently, hexane (4 ml) was added and vortex mixed again for 1 min. After that, saturated $\mathrm{NaCl}$ aqueous solution (2 ml) was added, the mixture was homogenised (1 min), centrifuged (Centurion K24OR-2003 refrigerated centrifuge, $5 \mathrm{~min}, 6185 \mathrm{rpm}$ ) and the clear upper layer was carefully transferred to a vial containing anhydrous sodium sulphate. The residue was re-extracted twice with hexane. The combined extracts were evaporated to dryness under a nitrogen stream, redissolved in $1 \mathrm{ml}$ of $\mathrm{n}$-hexane, filtered through a 0.22 $\mu \mathrm{m}$ disposable LC filter disk, transferred into a dark injection vial and analysed by HPLC. The equipment consisted of an integrated system consisted in a Smartline pump 1000 (Knauer, Germany), a degasser system Smartline manager 5000, an AS-2057 auto-sampler and a $2500 \mathrm{UV}$ detector at $295 \mathrm{~nm}$ (Knauer, Germany) connected in series with a FP-2020 fluorescence detector (Jasco, Japan) programmed for excitation at 290 $\mathrm{nm}$ and emission at $330 \mathrm{~nm}$. Data were analysed using Clarity 2.4 Software (DataApex). The chromatographic separation was performed using a Polyamide II $(250 \times 4.6 \mathrm{~mm})$ normal phase column from YMC Waters (Japan) operating at $30{ }^{\circ} \mathrm{C}$ (7971 R Grace oven). The mobile phase used was a mixture of n-hexane and ethyl acetate (70:30, v/v) at a flow rate of $1 \mathrm{ml} / \mathrm{min}$, and the injection volume was $10 \mu \mathrm{l}$. Tocopherols were identified by chromatographic comparisons with standards. Quantification was based on the fluorescence signal response, using the internal standard method. Tocopherols content in wild greens samples were expressed in $\mathrm{mg} / 100 \mathrm{~g}$ of dry weight (dw). 
Evaluation of total phenolics and flavonoids

Extracts preparation. A fine dried powder $(1 \mathrm{~g})$ was extracted by stirring with $40 \mathrm{ml}$ of methanol at $25{ }^{\circ} \mathrm{C}$ for $1 \mathrm{~h}$ and filtered through Whatman No. 4 filter paper. The residue was then extracted with one additional $40 \mathrm{ml}$ portion of methanol. The combined methanolic extracts were evaporated at $35^{\circ} \mathrm{C}$ under reduced pressure (rotary evaporator Büchi R-210), re-dissolved in methanol at a concentration of $5 \mathrm{mg} / \mathrm{ml}$, and stored at 4 ${ }^{\circ} \mathrm{C}$ for further use. The extraction yield (\%) of this procedure was calculated from the dry weight of the evaporated extracts.

Total phenolics and flavonoids. Total phenolics were estimated based on procedures described by Wolfe et al. (2003) with some modifications. An aliquot of the extract solution $(0.5 \mathrm{ml})$ was mixed with Folin-Ciocalteu reagent $(2.5 \mathrm{ml}$, previously diluted with water 1:10 v/v) and sodium carbonate $(75 \mathrm{~g} / \mathrm{l}, 2 \mathrm{ml})$. The tubes were vortexed for $15 \mathrm{~s}$ and allowed to stand for $30 \mathrm{~min}$ at $40{ }^{\circ} \mathrm{C}$ for colour development. Absorbance was then measured at $765 \mathrm{~nm}$ (AnalytikJena 200 spectrophotometer). Gallic acid was used to perform the standard curve $\left(5.0 \times 10^{-2}-0.8 \mathrm{mM}\right)$, and the results in samples were expressed as mg of gallic acid equivalents (GAEs) per g of extract.

Flavonoids content was determined using the method of Jia et al. (1999), with some modifications. An aliquot $(0.5 \mathrm{ml})$ of the extract solution was mixed with distilled water $(2 \mathrm{ml})$ and subsequently with $\mathrm{NaNO}_{2}$ solution $(5 \%, 0.15 \mathrm{ml})$. After 6 min, $\mathrm{AlCl}_{3}$ solution $(10 \%, 0.15 \mathrm{ml})$ was added and allowed to stand further $6 \mathrm{~min}$. Thereafter, $\mathrm{NaOH}$ solution $(4 \%, 2 \mathrm{ml})$ was added to the mixture and distilled water was immediately added to bring the final volume to $5 \mathrm{ml}$. Then the mixture was properly mixed and allowed to stand for $15 \mathrm{~min}$. The intensity of pink colour was measured at $510 \mathrm{~nm}$. To perform the standard curve $\left(1.6 \times 10^{-2}-1.0 \mathrm{mM}\right)(+)$-catechin was used and 
the results were expressed as $\mathrm{mg}$ of $(+)$-catechin equivalents (CEs) per $\mathrm{g}$ of extract.

Evaluation of the antioxidant activity

DPPH radical-scavenging activity. This methodology was performed using an ELX800 Microplate Reader (Bio-Tek Instruments, Inc.), according to Barros et al. (2010). The reaction mixture in each one of the 96-wells consisted of one of the different concentrations of the extracts $(30 \mu \mathrm{l})$ and aqueous methanolic solution $(80: 20 \mathrm{v} / \mathrm{v}, 270$ ul) containing DPPH radicals $\left(6 \times 10^{5} \mathrm{~mol} / \mathrm{l}\right)$. The mixture was left to stand for $60 \mathrm{~min}$ in the dark. The reduction of the DPPH radical was determined by measuring the absorption at $515 \mathrm{~nm}$. The radical-scavenging activity (RSA) was calculated as a percentage of DPPH discolouration using the equation: \% RSA $=\left[\left(A_{D P P H}-A_{S}\right) / A_{D P P H}\right]$ $\times 100$, where $A_{S}$ is the absorbance of the solution when the sample extract has been added at a particular level, and $\mathrm{A}_{\mathrm{DPPH}}$ is the absorbance of the DPPH solution. The extract concentration providing $50 \%$ of radicals scavenging activity $\left(\mathrm{EC}_{50}\right)$ was calculated from the graph of RSA percentage against extract concentration. Trolox was used as standard.

Reducing power. Different concentrations of the extracts $(0.5 \mathrm{ml})$ were mixed with sodium phosphate buffer $(200 \mathrm{mmol} / \mathrm{l}, \mathrm{pH} 6.6,0.5 \mathrm{ml})$ and potassium ferricyanide $(1 \%$ $\mathrm{w} / \mathrm{v}, 0.5 \mathrm{ml}$ ). The mixture was incubated at $50{ }^{\circ} \mathrm{C}$ for $20 \mathrm{~min}$, and trichloroacetic acid $(10 \% \mathrm{w} / \mathrm{v}, 0.5 \mathrm{ml})$ was added. The mixture $(0.8 \mathrm{ml})$ was poured in the 48 -wells, as also deionised water $(0.8 \mathrm{ml})$ and ferric chloride $(0.1 \% \mathrm{w} / \mathrm{v}, 0.16 \mathrm{ml})$, and the absorbance was measured at $690 \mathrm{~nm}$ in the Microplate Reader described above (Barros et al. 2010). The extract concentration providing 0.5 of absorbance $\left(\mathrm{EC}_{50}\right)$ was calculated from the graph of absorbance at $690 \mathrm{~nm}$ against extract concentration. Trolox was used as 
standard.

Inhibition of $\beta$-carotene bleaching. A solution of $\beta$-carotene was prepared by dissolving $\beta$-carotene $(2 \mathrm{mg})$ in chloroform $(10 \mathrm{ml})$. Two millilitres of this solution were pipetted into a round-bottom flask. After the chloroform was removed at $40{ }^{\circ} \mathrm{C}$ under vacuum, linoleic acid (40 mg), Tween 80 emulsifier (400 mg), and distilled water (100 ml) were added to the flask with vigorous shaking. Aliquots $(4.8 \mathrm{ml})$ of this emulsion were transferred into different test tubes containing different concentrations of the extracts $(0.2 \mathrm{ml})$. The tubes were shaken and incubated at $50{ }^{\circ} \mathrm{C}$ in a water bath (Barros et al. 2010). As soon as the emulsion was added to each tube, the zero time absorbance was measured at $470 \mathrm{~nm}$. The inhibition of $\beta$-Carotene bleaching was calculated using the following equation: ( $\beta$-carotene content after $2 \mathrm{~h}$ of assay/initial $\beta$-carotene content $) \times$ 100. The extract concentration providing $50 \%$ antioxidant activity $\left(\mathrm{EC}_{50}\right)$ was calculated by interpolation from the graph of $\beta$-carotene bleaching inhibition percentage against extract concentration. Trolox was used as standard.

Inhibition of lipid peroxidation by TBARS assay. Brains were obtained from pig (Sus scrofa) of body weight $\sim 150 \mathrm{~kg}$, dissected and homogenized with a Polytron in ice-cold Tris- $\mathrm{HCl}$ buffer $(20 \mathrm{mM}, \mathrm{pH} 7.4)$ to produce a 1:2 (w/v) brain tissue homogenate, which was centrifuged at $3000 \mathrm{~g}$ for $10 \mathrm{~min}$. An aliquot $(0.1 \mathrm{ml})$ of the supernatant was incubated with the different concentrations of the extracts $(0.2 \mathrm{ml})$ in the presence of $\mathrm{FeSO}_{4}(10 \mu \mathrm{M} ; 0.1 \mathrm{ml})$ and ascorbic acid $(0.1 \mathrm{mM} ; 0.1 \mathrm{ml})$ at $37{ }^{\circ} \mathrm{C}$ for $1 \mathrm{~h}$. The reaction was stopped by the addition of trichloroacetic acid $(28 \% \mathrm{w} / \mathrm{v}, 0.5 \mathrm{ml})$, followed by thiobarbituric acid (TBA, $2 \% \mathrm{w} / \mathrm{v}, 0.38 \mathrm{ml}$ ), and the mixture was then heated at 80 ${ }^{\circ} \mathrm{C}$ for $20 \mathrm{~min}$. After centrifugation at $3000 \mathrm{~g}$ for $10 \mathrm{~min}$ to remove the precipitated 
protein, the colour intensity of the malondialdehyde (MDA)-TBA complex in the supernatant was measured by its absorbance at $532 \mathrm{~nm}$ (Barros et al. 2010). The inhibition ratio (\%) was calculated using the following formula: Inhibition ratio $(\%)=$ $[(\mathrm{AxB}) / \mathrm{A}] \mathrm{x} 100 \%$, where $\mathrm{A}$ and $\mathrm{B}$ were the absorbance of the control and the extract solution, respectively. The extract concentration providing 50\% lipid peroxidation inhibition $\left(\mathrm{EC}_{50}\right)$ was calculated from the graph of TBARS inhibition percentage against extract concentration. Trolox was used as standard.

Statistical analysis

Analysis of variance (ANOVA), followed by Turkey's test was conducted using Statgraphics Plus 5.1. software to analyze data at the 95\% confidence level. Values were expressed as means of triplicate analyses and corresponding standard deviations. Likewise, correlation analysis was performed among the variables analyzed.

\section{Results and discussion}

Tocopherols composition

Table 2 shows the tocopherols composition of the wild vegetables analyzed. Comparing the tocopherol content of leafy vegetables and wild asparagus, significant differences $(p<0.05)$ can be observed for $\alpha, \beta$ and total tocopherols contents. $\alpha$ Tocopherol, which is the most active isoform of vitamin E (Caretto et al. 2009), was the predominant isoform in all the leafy vegetables analysed. However, as it will be described below, in the four wild asparagus studied other forms were also codominant or even predominant. 
The species with the highest $\alpha$-tocopherol content $(10.12 \mathrm{mg} / 100 \mathrm{~g} \mathrm{dw})$ was Silene vulgaris; the specific tocopherols profile of Silene vulgaris is shown in Figure 1. The wild asparagus Humulus lupulus showed the highest total tocopherols content (14.32 $\mathrm{mg} / 100 \mathrm{~g})$ although the mayor isoform was $\gamma$-tocopherol $(8.98 \mathrm{mg} / 100 \mathrm{~g})$. Besides Silene vulgaris, other leafy vegetable with a high $\alpha$-tocopherol and total tocopherols content was Montia fontana. Low amounts of $\beta$-tocopherol and $\gamma$-tocopherol appeared in this group of plants while $\delta$-tocopherol was not found in Apium nodiflorum and Foeniculum vulgare. The last result is in agreement with a previous study of our research group in Portuguese samples (Barros et al. 2009).

As pointed before, in the wild asparagus both $\alpha$-tocopherol and $\gamma$-tocopherol were the main responsible for total vitamin E activity. The most abundant isoform in Asparagus acutifolius and Bryonia dioica was $\alpha$-tocopherol $(1.89 \mathrm{mg} / 100 \mathrm{~g}$ and $0.75 \mathrm{mg} / 100 \mathrm{~g} \mathrm{dw}$, respectively), while in Humulus lupulus and Tamus communis the mayor isoform was $\gamma$ tocopherol $(8.98 \mathrm{mg} / 100 \mathrm{~g}$ and $1.85 \mathrm{mg} / 100 \mathrm{~g} \mathrm{dw}$ respectively). In contrast to the leafy vegetables considered, $\delta$-tocopherol was detected in all the samples of wild asparagus.

The four isoforms ( $\alpha, \beta, \gamma$ and $\delta$-tocopherol) have been identified and quantified in other wild vegetables, as previously reported by several authors (Vardavas et al. 2006; Barros et al. 2009). Comparing our data with those reports, the Spanish samples of Silene vulgaris and Foeniculum vulgare revealed a higher tocopherols content than the Cretan (Vardavas et al. 2006) and Portuguese (Barros et al. 2009) ones, respectively. However, Portuguese samples of Asparagus acutifolius, Bryonia dioica and Tamus communis (Martins et al. 2011) showed higher tocopherols content than the Spanish ones. The mentioned variability could be explained by different climatic and soil conditions as well as by postharvest conditions (Prohens et al. 2005). Moreover, total tocopherols content $(2.1 \mathrm{mg} / 100 \mathrm{~g})$ supplied by cultivated Asparagus officinalis (Souci 
et al. 2008) is lower than the one obtained in wild Asparagus acutifolius herein studied. The differences found in the distribution of the tocopherol isoforms between the two groups of wild vegetables might be related to the part of the plant considered. It has been suggested that chlorophyll is always accompanied by $\alpha$-tocopherol, which is probably sited inside chloroplasts while $\gamma$-tocopherol is mainly outside chloroplasts (Booth 1963). Therefore, $\alpha$-tocopherol concentration is higher in leaves than in stems and, consequently higher in the leafy vegetables than in the wild asparagus considered.

Total phenolics and flavonoids

Phenolics and flavonoids content in the analyzed samples are shown in Table 3. Among the leafy vegetables, Apium nodiflorum had the highest total content of phenolics $(80.47$ mg GAE/g extract) and flavonoids (45.48 mg CE/g extract), while Silene vulgaris and Foeniculum vulgare, revealed the lowest ones $(26.72 \mathrm{mg}$ GAE/g extract and $9.72 \mathrm{mg}$ $\mathrm{CE} / \mathrm{g}$ extract, respectively).

The highest extraction yield $(29.67 \%)$ was obtained for Foeniculum vulgare. Similar values were reported for the Portuguese (Barros et al. 2009) and the Iranian fennel (Motamed and Naghibi 2010), but lower values for the Italian one (Conforti et al. 2009). However, our sample of Foeniculum vulgare showed a higher total phenolic content than the Portuguese (8.61 mg GAE/g extract) and the Iranian fennel (7.74 mg GAE/g,) samples, but lower than the Italian one $(80 \mathrm{mg} \mathrm{GAE} / \mathrm{g})$. Despite the lower total phenolics content found in Iranian fennel, its flavonoids content (16.49 mg CE/g) was higher than the samples analysed in this study. Therefore, our results suggest that there is not a direct relationship between extraction yield and phenolics content in this kind of samples, probably due to the extraction of other methanol soluble components, such as sugars. 
Regarding wild asparagus, Humulus lupulus presented the highest total phenolic content (55.83 mg GAE/g extract) while Bryonia dioica showed the highest flavonoids content (16.31 mg CE/ g extract). Phenolic content in Humulus lupulus was significantly higher than that reported by Wojdylo et al. (2007) in Poland samples (7.14 mg GAE/g extract). However, Portuguese samples of Asparagus acutifolius, Bryonia dioica and Tamus communis (Martins et al. 2011) revealed a significantly higher content of phenolics (624 $\mathrm{mg} \mathrm{GAE} / \mathrm{g}$ extract, $258 \mathrm{mg} \mathrm{GAE} / \mathrm{g}$ extract and $759 \mathrm{mg} \mathrm{GAE} / \mathrm{g}$ extract, respectively) and flavonoids (57.8 mg CE/ g extract, $18.1 \mathrm{mg} \mathrm{CE} / \mathrm{g}$ extract and $150 \mathrm{mg} \mathrm{CE} / \mathrm{g}$ extract, respectively) than the Spanish samples herein studied. Asparagus acutifolius have shown the lowest total phenolics and flavonoids content (17.60 mg GAE/g extract and $6.09 \mathrm{mg} \mathrm{CE} / \mathrm{g}$ extract) but the highest extraction yield (46.14\%).

Overall, phenolic content varied from 80.47 to $17.60 \mathrm{mg}$ GAE/g extract. Apium nodiflorum showed the highest values while Asparagus acutifolius the lowest ones. Leafy vegetables had statistically higher amounts of total phenolics than wild asparagus. Regarding total flavonoids content, it has ranged between 45.48 and $6.09 \mathrm{mg} \mathrm{CE} / \mathrm{g}$ extract. Similar patterns have been found in Apium nodiflorum, which reached again the highest values, and Asparagus acutifolius, which showed the lowest ones.

Antioxidant activity

Figure 2 shows the antioxidant properties of the studied vegetables using different assays based on different concentration of the methanolic extract: scavenging activity on DPPH radicals, reducing power and lipid peroxidation inhibition by $\beta$-carotenelinoleate system and TBARS assay. The $\mathrm{EC}_{50}$ values $(\mathrm{mg} / \mathrm{ml})$ obtained in each 
antioxidant activity assay are given in Table $\mathbf{3}$.

Statistical analysis applied to phenolics and flavonoids data clearly differentiated between leafy vegetables (lower $\mathrm{EC}_{50}$ values, and thus higher antioxidant activity) and wild asparagus samples (lower antioxidant activity), except for $\beta$-carotene bleaching inhibition capacity, in which almost all the species presented a similar action.

Among the leafy vegetables, Apium nodiflorum presented DPPH radical-scavenging activity (RSA) around $80 \%$ at $0.25 \mathrm{mg} / \mathrm{ml}$ (Figure 2a), while Montia fontana gave $80 \%$ of RSA at $4 \mathrm{mg} / \mathrm{ml}$. However, Foeniculum vulgare and Silene vulgaris presented RSA only around $60 \%$ at the same concentration $(4 \mathrm{mg} / \mathrm{ml})$. Similar values to those of Montia fontana were also found in this assay for Humulus lupulus. The other wild asparagus reached lower percentages than $60 \%$ of RSA at $4 \mathrm{mg} / \mathrm{ml}$.

Foeniculum vulgare and the four wild asparagus showed the lowest reducing power values, with absorbances lower than 1.61 at $2 \mathrm{mg} / \mathrm{ml}$ (Figure 2b), whereas Apium nodiflorum revealed again the highest reducing power, followed by Montia fontana. Absorbance of 3.74 at $0.25 \mathrm{mg} / \mathrm{ml}$ and an $\mathrm{EC}_{50}$ value of $0.02 \mathrm{mg} / \mathrm{ml}$ were described for Apium nodiflorum (Table 3).

In $\beta$-carotene bleaching inhibition assay, Apium nodiflorum was, once more, the species with the highest capacity (higher than $85 \%$ at $1 \mathrm{mg} / \mathrm{ml}$; Figure $2 \mathrm{c}$ ). Otherwise, Silene vulgaris presented the highest $\mathrm{EC}_{50}$ value $(0.62 \mathrm{mg} / \mathrm{ml})$ of both leafy vegetables and wild asparagus groups.

In TBARS assay, Foeniculum vulgare presented a lipid peroxidation inhibition capacity higher than $80 \%$ at $0.125 \mathrm{mg} / \mathrm{ml}$, as also Montia fontana (Figure 2d), both with $\mathrm{EC}_{50}$ values of $0.02 \mathrm{mg} / \mathrm{ml}$ (Table 3). Apium nodiflorum and Silene vulgaris presented at the same concentration $(0.125 \mathrm{mg} / \mathrm{ml})$ an inhibition capacity slightly lower, ranging from 73 to $78 \%$. 
According to other studies which have assessed the antioxidant activity of these wild vegetables, Spanish fennel (Foeniculum vulgare) gave much lower $\mathrm{EC}_{50}$ values than Portuguese fennel in the four assays (Barros et al. 2009; Mata et al. 2007), similar DPPH scavenging activity to the Iranian sample (2 mg/ml; Hinneburg et al. 2006), and lower DPPH scavenging activity, but higher TBARS inhibition than Italian fennel $(0.15$ $\mathrm{mg} / \mathrm{ml}$ and $0.25 \mathrm{mg} / \mathrm{ml}$; Conforti 2009). In adition, Wojdylo et al. (2007) reported a higher $\mathrm{EC}_{50}$ value for Poland samples of Humulus lupulus $(83.2 \mathrm{mg} / \mathrm{ml})$, which indicate a higher antioxidant capacity of the Spanish sample. The Local Food-Nutraceuticals Consortium (2005) reported for Bryonia dioica an activity lower than $30 \%$ at $1 \mathrm{mg} / \mathrm{ml}$ of the methanolic extract. Comparing with the Portuguese samples of Asparagus acutifolius, Bryonia dioica and Tamus communis (Martins et al. 2011), the Spanish samples presented higher $\mathrm{EC}_{50}$ values, except for TBARS assay, indicating lower effects in the Spanish samples.

Overall, Apium nodiflorum proved to have the most promising antioxidant properties, which is in agreement with its highest total phenolics and flavonoids contents. Furthermore, the traditional mode of consumption of Apium nodiflorum, i.e., eaten raw in salads, is the best way to preserve its antioxidant activity. However, Silene vulgaris, which revealed the highest $\alpha$-tocopherol and total tocopherols content, did not show a high antioxidant activity in any of the four different assays. It will be subsequently discussed with the results from the correlation analysis.

The correlation coefficient between the analysed compounds and antioxidant capacity of the studied wild vegetables are given in Table 4. Total tocopherol content was correlated $(\mathrm{r}=-0.67,-0.47$ and -0.60$)$ with most of the methods for antioxidant activity analysis applied in this study (DPPH, reduding power and TBARS assays, respectively). Similar correlations were described for $\alpha$-tocopherol $(\mathrm{r}=-0.59,-0.48$ and -0.52$)$ while 
the other three isoforms were lowly correlated. Thus, $\alpha$-tocopherol has been proved to be quite an interesting compound in leafy vegetables, and the negative correlation indicates that this compound is highly responsible for the antioxidant activity in the samples. However, $\beta$-carotene bleaching inhibition assay was only correlated with $\delta$ tocopherol $(\mathrm{r}=-0.47)$.

Total phenolics content can also be considered as a good indicator of antioxidant activity in the vegetables analysed, as it presented significant positive correlations with total tocopherols $(r=0.48)$ and flavonoids $(r=0.48)$. Significant negative correlations were also described with the $\mathrm{EC}_{50}$ values measured by the four antioxidant assays $(\mathrm{r}=$ $0.77,-0.80,-0.54$ and -0.52 , respectively), in agreement with Zheng and Wang (2001).

Similar considerations can be done for total flavonoids content, although it was not correlated neither with total tocopherols content nor with tocopherol isoforms separately. Nevertheless, significant negative correlations were recorded with all the antioxidant activity assays $(\mathrm{r}=-0.57,-0.76$, and -0.63 , respectively), with the exception of TBARS assay.

Regarding the different antioxidant assays performed, there was a strongly positive correlation between almost all the antioxidant assays, with the exception of $\beta$-carotene bleaching inhibition and TBARS assay. Significant correlation was not described between these two assays, probably due to the differences in their mechanism of action. The inhibition of $\beta$-carotene bleaching is a specific study against the oxidation of linoleic acid whereas TBARS assay evaluate the antioxidant action against all lipidic fractions. Nevertheless, a strongly correlation between DPPH and reducing power assays $(r=0.90)$, and TBARS assay with both DPPH and reducing power assays $(r=$ 0.70 and 0.70 respectively) was found. 
In general terms, all the methods used to measure antioxidant activity in foods have some limitations, as it has been observed in this study. For that reason, a combination of several methods is often needed. However, our results suggest that DPPH and reducing power methods are highly correlated with other methods, and thus one of them could be selected as indicator of the antioxidant activity of wild vegetables.

Tocopherols composition of Apium nodiflorum, Montia fontana and Humulus lupulus was reported in this study for the first time. From the results obtained we can conclude that the leafy vegetables Apium nodiflorum and Montia fontana presented the best antioxidant capacity, with the lowest $\mathrm{EC}_{50}$ values in all the antioxidant assays performed. The first one has showed a significantly higher antioxidant activity than the other species, which could be attributed to its highest total phenolics and flavonoids contents. In Montia fontana, the antioxidant activity was probably due both to its high total phenolics and flavonoids, as well as its tocopherols content, especially $\alpha$ tocopherol. However, Silene vulgaris, the species with the highest total tocopherols content but with low content of phenolics and flavonoids, did not show a significantly high antioxidant activity.

Moreover, three of the species of leafy vegetables considered, Apium nodiflorum, Foeniculum vulgare, and Montia fontana are usually consumed fresh, mainly in salads. Since processing and cooking can affect the concentration, activity and availability of natural antioxidants (Nicoli et al. 1999), vegetables consumed raw would preserve better their antioxidant capacity.

In general terms, wild asparagus showed lower antioxidant activity than the leafy 
vegetables considered. Among the four species, Humulus lupulus presented the highest antioxidant capacity, probably due to its highest phenolics and total tocopherols content. Therefore, the wild edible species studied could be selected because of their nutritional interest and high antioxidant capacity. The minority consumption of these plants in present-days could be invigorated for this reason. Moreover, as sources of powerful antioxidants, they should be recovered for use as functional foods or as potential functional ingredients for food industry.

\section{Acknowledgements}

The authors are grateful to ERDF and the Spanish Ministry of Education and Science (CGL2006-09546/BOS) and to Foundation for Science and Technology (Portugal) for financial support. The authors also thank Ramón Morales, Manuel Pardo de Santayana, Laura Aceituno, Susana González and Javier Tardío for their collaboration in gathering and preparing the samples, and also to Javier Tardío for coordination and for checking the manuscript.

\section{References}

Barros L, Heleno SA, Carvalho AM, Ferreira ICFR (2009) Systematic evaluation of the antioxidant potential of different parts of Foeniculum vulgare Mill. from Portugal. Food Chem Toxicol 47:2458-2464.

Barros L, Heleno SA, Carvalho AM, Ferreira ICFR (2010) Lamiaceae often used in Portuguese folk medicine as a source of powerful antioxidants: vitamins and phenolics. LWT- Food Sci Technol 43:544-550.

Biglino G, Nano GM (1965) Partial synthesis of bryogenine. XII. Constituents of Bryonia dioica root. Farmaco 20:566-569. 
Booth VH (1963) $\alpha$-Tocopherol, its co-occurrence with chlorophyll in chloroplasts Phytochemistry 2:421-427.

Bravo L (1998) Polyphenols: chemistry, dietary sources, metabolism, and nutritional significance. Nutr Rev 56:317-333.

Burton GW, Traber MG (1990) Vitamin E: antioxidant activity, biokinetics, and bioavailability. Annu Rev Nutr 10:357-382.

Caretto S, Nisi R, Paradiso A, DeGara L (2009) Tocopherol production in plant cell cultures. Free Radical Res 43:S27-97.

Carvalho AM (2010) Plantas y sabiduría popular del Parque Natural de Montesinho. Un estudio etnobotánico en Portugal. Biblioteca de Ciencias 35. Madrid: Consejo Superior de Investigaciones Científicas.

Conforti F, Sosa S, Marrelli M, Menichini M, Statti GA, Uzunov D, Tubaro A, Menichini F (2009) The protective ability of Mediterranean dietary plants against the oxidative damage: the role of radical oxygen species in inflammation and the polyphenol, flavonoid and sterol contents. Food Chem 112:587-594.

Couplan F (1990) Les belles veneneuses. Encyclopedie des plantes comestibles de l'Europe, Vol. 3. Flers: Equilibres Aujourd'houi.

Craig WJ (1999) Health-promoting properties of common herbs. Am J Clin Nutr 70:491S-499S.

Di Matteo V, Esposito E (2003) Biochemical and therapeutic effects of antioxidants in the treatment of Alzheimer's disease, Parkinson's disease, and amyotrophic lateral sclerosis. CNS Neurol Disord-Dr 2:95-107. 
Ferreira ICFR, Barros L, Abreu RMV (2009) Antioxidants in wild mushrooms. Curr Med Chem 16:1543-1560.

Gerber M, Boutron-Ruault MC, Hercberg S, Riboli E, Scalbert A, Siess MH (2002) Food and cancer: state of the art about the protective effect of fruits and vegetables. Bull Cancer 89:293-312.

Hadad Chi, GR., Moradi Z. (2005) The amounts and distribution of diosgenin and saponin and their carbohydrate moiety of Tamus communis L. J Agric Sci Technol 12:55-66.

Hinneburg I, Dorman HJD, Hiltunen R (2006) Antioxidant activity of extracts from selected culinary herbs and spices. Food Chem 97:122-129.

Jia Z, Tang M, Wu J (1999) The determination of flavonoid contents in mulberry and their scavenging effects on superoxide radicals. Food Chem 64:555-559.

Kamal-Eldin A, Appelqvist LA (1996) The chemistry and antioxidant properties of tocopherols and tocotrienols. Lipids 31:671-701.

Lin JT, Liu SC, Chen SL, Chen HY, Yang DJ (2006) Effects of domestic processing on steroidal saponins in taiwanese yam cultivar (Dioscorea pseudojaponica Yamamoto). J Agr Food Chem 54:9948-9954.

Mata AT, Proença C, Ferreira AR, Serralheiro MLM, Nogueira JMF, Araujo MEM (2007) Antioxidant and antiacetylcholinesterase activities of five plants used as Portuguese food spices. Food Chem 103:778-786.

Martins D, Barros L, Carvalho AM, Ferreira ICFR (2011) Nutritional and in vitro antioxidant properties of edible wild greens in Iberian Peninsula traditional diet. Food Chem 125:488-494. 
Moreira PI, Santos MS, Oliveira CR, Shenk JC, Nunomura A, Smith MA, Zhu X, Perry G (2008) Alzheimer disease and the role of free radicals in the pathogenesis of the disease. CNS Neurol Disord-Dr 7:3-10.

Motamed SM, Naghibi F (2010) Antioxidant activity of some edible plants of the Turkmen Sahra region in northern Iran. Food Chem 119:1637-1642.

Nicoli MC, Anese M, Parpinel M (1999) Influence of processing on the antioxidant properties of fruit and vegetables. Trends Food Sci Technol 10:94-100.

Nijveldt R, Nood E, Hoorn D, Boelens P, Norren K, Leeuwen P (2001) Flavonoids: a review of probable mechanisms of action and potential applications. Am J Clin Nutr 74:418-425.

Prohens J, Sánchez MC, Rodríguez-Burruezo A, Cámara M, Torija E, Nuez F (2005) Morphological and physico-chemical characteristics of fruits of pepino (Solanum muricatum), wild relatives ( $S$. caripense and $S$. tabanoense) and interspecific hybrids. Implications in pepino breeding. Europe J Hort Sci 70:224-230.

Schwenke DC (2002) Does lack of tocopherols and tocotrienols put women at increased risk of breast cancer? J Nutr Biochem 13:2-20.

Shah AM, Channon KM (2004) Free radicals and redox signalling in cardiovascular disease. Heart 90:486-487.

Siegall CB, Gawlak SL, Chace D, Wolff EA, Mixan B, Marquardt H (1994) Characterization of ribosome-inactivating proteins isolated from Bryonia dioica and their utility as carcinoma-reactive immunoconjugates. Bioconjugate Chem $5: 423-429$.

Souci SW, Fachmann W, Kraut G (2008) Food composition and nutrition tables. 7th revised and completed edition, Taylor \& Francis A CRC Press Book, USA. 
Tardío J, Pascual H, Morales R (2005) Wild food plants traditionally used in the province of Madrid, Central Spain. Econ Bot 59:122-136.

Tardío J, Pardo-de-Santayana M, Morales R (2006) Ethnobotanical review of wild edible plants in Spain. Bot J Linn Soc 152:27-71.

Tardío J (2010) Spring is coming. The gathering and consumption of wild vegetables in Spain. In M. Pardo-de-Santayana, A. Pieroni, R. Puri. Ethnobotany in the New Europe. UK: Berghahn Books, 211-237.

The Local Food-Nutraceuticals Consortium (2005) Understanding local Mediterranean diets: a multidisciplinary pharmacological and ethnobotanical approach. Pharmacol Res 52:353-366.

Valko M, Rhodes CJ, Moncol J, Izakovic M, Mazur M (2006) Free radicals, metals and antioxidants in oxidative stress-induced cancer. Chem Biol Interact 160:1-40.

Vardavas CI, Majchrzak D, Wagner KH, Elmadfa I, Kafatos A (2006) The antioxidant and phylloquinone content of wildly grown greens in Crete. Food Chem 99:813821.

Wojdylo A, Oszmianski J, Czemerys R (2007) Antioxidant activity and phenolic compounds in 32 selected herbs. Food Chem 105:940-949.

Wolfe K, Wu X, Liu RH (2003) Antioxidant activity of apple peels. J Agric Food Chem 51:609-614.

Yang Y, Guo J, Yuan Y (2008) In vitro antioxidant properties of rutin. LWT- Food Sci Technol 41:1060-1066. 
Zheng W, Wang S (2001) Antioxidant activity and phenolic composition in selected herbs. J Agric Food Chem 49:5165-5170. 
Table 1. Information related to samples harvesting.

\begin{tabular}{|c|c|c|c|c|c|c|c|c|c|c|}
\hline & \multicolumn{5}{|c|}{ Site 1} & \multicolumn{5}{|c|}{ Site 2} \\
\hline & Location & $\begin{array}{l}\text { Altitude } \\
(\mathrm{m})\end{array}$ & $\begin{array}{l}\text { Geographical } \\
\text { coordinates }\end{array}$ & $\begin{array}{l}\text { Dates of } \\
\text { collection }\end{array}$ & $\begin{array}{l}\text { Harvesting } \\
\text { places }^{1}\end{array}$ & Location & $\begin{array}{l}\text { Altitude } \\
(\mathrm{m})\end{array}$ & $\begin{array}{l}\text { Geographical } \\
\text { coordinates }\end{array}$ & $\begin{array}{l}\text { Dates of } \\
\text { collection }\end{array}$ & $\begin{array}{l}\text { Harvesting } \\
\text { places }^{1}\end{array}$ \\
\hline \multicolumn{11}{|l|}{ Leafy vegetables } \\
\hline Apium nodiflorum & $\begin{array}{l}\text { Perales de } \\
\text { Tajuña }\end{array}$ & 595 & $\begin{array}{l}40^{\circ} 14^{\prime} \mathrm{N} ; \\
3^{\circ} 21^{\prime} \mathrm{W}\end{array}$ & $\begin{array}{l}\text { 21/03/2007; } \\
21 / 04 / 2008 \\
30 / 03 / 2009\end{array}$ & $\mathrm{AE}$ & $\begin{array}{l}\text { Villar del } \\
\text { Olmo }\end{array}$ & 675 & $\begin{array}{l}40^{\circ} 20^{\prime} \mathrm{N} \\
3^{\circ} 14^{\prime} \mathrm{W}\end{array}$ & $\begin{array}{l}07 / 04 / 2008 \\
30 / 03 / 2009\end{array}$ & $\mathrm{AE}$ \\
\hline Foeniculum vulgare & $\begin{array}{l}\text { Perales de } \\
\text { Tajuña }\end{array}$ & 595 & $\begin{array}{l}40^{\circ} 14^{\prime} \mathrm{N} ; \\
3^{\circ} 21^{\prime} \mathrm{W}\end{array}$ & $\begin{array}{l}09 / 05 / 2007 \\
12 / 05 / 2008\end{array}$ & $\begin{array}{l}\text { CL, UL, } \\
\text { PA }\end{array}$ & Cantoblanco & 690 & $\begin{array}{l}40^{\circ} 32^{\prime} \mathrm{N} \\
3^{\circ} 41^{\prime} \mathrm{W}\end{array}$ & $\begin{array}{l}09 / 05 / 2007 \\
07 / 05 / 2008\end{array}$ & $\mathrm{UL}, \mathrm{PA}$ \\
\hline Montia fontana & $\begin{array}{l}\text { Ituero y } \\
\text { Lama }\end{array}$ & 1020 & $\begin{array}{l}40^{\circ} 49^{\prime} \mathrm{N} \\
4^{\circ} 23^{\prime} \mathrm{W}\end{array}$ & $\begin{array}{l}31 / 03 / 2008 \\
25 / 03 / 2009\end{array}$ & $\mathrm{AE}$ & Rascafría & 1700 & $\begin{array}{l}40^{\circ} 50^{\prime} \mathrm{N} ; \\
3^{\circ} 49^{\prime} \mathrm{W}\end{array}$ & $\begin{array}{l}23 / 04 / 2008 \\
27 / 04 / 2009\end{array}$ & $\mathrm{AE}$ \\
\hline Silene vulgaris & $\begin{array}{l}\text { Cadalso de } \\
\text { los Vidrios }\end{array}$ & 780 & $\begin{array}{l}40^{\circ} 18^{\prime} \mathrm{N} \\
4^{\circ} 26^{\prime} \mathrm{W}\end{array}$ & $\begin{array}{l}28 / 03 / 2007 \\
12 / 03 / 2008\end{array}$ & CL, PA & $\begin{array}{l}\text { Villar del } \\
\text { Olmo }\end{array}$ & 675 & $\begin{array}{l}40^{\circ} 20^{\prime} \mathrm{N} \\
3^{\circ} 14^{\prime} \mathrm{W}\end{array}$ & $\begin{array}{l}25 / 04 / 2007 \\
07 / 04 / 2008\end{array}$ & $\mathrm{CL}, \mathrm{PA}$ \\
\hline \multicolumn{11}{|l|}{ Wild asparagus } \\
\hline Asparagus acutifolius & Cantoblanco & 690 & $\begin{array}{l}40^{\circ} 32^{\prime} \mathrm{N} \\
3^{\circ} 41^{\prime} \mathrm{W}\end{array}$ & $\begin{array}{l}\text { 11/04/2007; } \\
14 / 04 / 2008 \\
13 / 04 / 2009\end{array}$ & $\mathrm{FO}$ & $\begin{array}{l}\text { Alcalá de } \\
\text { Henares }\end{array}$ & 600 & $\begin{array}{l}40^{\circ} 31^{\prime} \mathrm{N} ; \\
3^{\circ} 17^{\prime} \mathrm{W}\end{array}$ & $\begin{array}{l}09 / 04 / 2008 \\
26 / 04 / 2009\end{array}$ & FO \\
\hline Bryonia dioica & Cantoblanco & 690 & $\begin{array}{l}40^{\circ} 32^{\prime} \mathrm{N} \\
3^{\circ} 41^{\prime} \mathrm{W}\end{array}$ & $\begin{array}{l}18 / 04 / 2007 \\
14 / 04 / 2008\end{array}$ & $\mathrm{FO}$ & $\begin{array}{l}\text { Alcalá de } \\
\text { Henares }\end{array}$ & 600 & $\begin{array}{l}40^{\circ} 31^{\prime} \mathrm{N} ; \\
3^{\circ} 17^{\prime} \mathrm{W}\end{array}$ & $\begin{array}{l}25 / 04 / 2007 \\
02 / 04 / 2008\end{array}$ & FO \\
\hline Humulus lupulus & $\begin{array}{l}\text { Alcalá de } \\
\text { Henares }\end{array}$ & 600 & $\begin{array}{l}40^{\circ} 31^{\prime} \mathrm{N} \\
3^{\circ} 17^{\prime} \mathrm{W}\end{array}$ & $\begin{array}{l}23 / 05 / 2007 \\
02 / 04 / 2008\end{array}$ & $\mathrm{FO}$ & $\begin{array}{l}\text { Miraflores } \\
\text { de la Sierra }\end{array}$ & 1147 & $\begin{array}{l}40^{\circ} 48^{\prime} \mathrm{N} ; \\
3^{\circ} 46^{\prime} \mathrm{W}\end{array}$ & $\begin{array}{l}28 / 05 / 2007 \\
23 / 04 / 2008\end{array}$ & $\mathrm{FO}$ \\
\hline Tamus communis & Tres Cantos & 750 & $\begin{array}{l}40^{\circ} 36^{\prime} \mathrm{N} \\
3^{\circ} 42^{\prime} \mathrm{W}\end{array}$ & $\begin{array}{l}\text { 16/05/2007; } \\
16 / 04 / 2008\end{array}$ & $\mathrm{FO}$ & $\begin{array}{l}\text { Soto del } \\
\text { Real }\end{array}$ & 921 & $\begin{array}{l}40^{\circ} 45^{\prime} \mathrm{N} \\
3^{\circ} 47^{\prime} \mathrm{W}\end{array}$ & $\begin{array}{l}16 / 05 / 2007 \\
16 / 04 / 2008\end{array}$ & FO \\
\hline
\end{tabular}


Table 2. Tocopherols composition ( $\mathrm{mg} / 100 \mathrm{~g} \mathrm{dw})$ of the wild vegetables. Different letters mean significant differences in each column $(\mathrm{p}<0.05)$.

\begin{tabular}{|c|c|c|c|c|c|}
\hline & $\alpha$-Tocopherol & $\beta$-Tocopherol & $\gamma$-Tocopherol & $\delta$-Tocopherol & Total \\
\hline \multicolumn{6}{|l|}{ Leafy vegetables } \\
\hline Apium nodiflorum & $2.59 \pm 0.03^{\mathrm{d}}$ & $0.25 \pm 0.00^{\mathrm{d}}$ & $0.21 \pm 0.00^{\mathrm{a}}$ & n.d & $3.05 \pm 0.03^{c}$ \\
\hline Foeniculum vulgare & $3.25 \pm 0.96^{\mathrm{de}}$ & $0.59 \pm 0.19^{f}$ & $0.52 \pm 0.29^{\mathrm{a}}$ & n.d & $4.36 \pm 0.96^{\mathrm{d}}$ \\
\hline Montia fontana & $6.01 \pm 0.07^{\mathrm{f}}$ & $0.25 \pm 0.01^{\mathrm{de}}$ & $1.41 \pm 0.02^{\mathrm{d}}$ & $0.36 \pm 0.04^{\mathrm{b}}$ & $8.03 \pm 0.05^{\mathrm{e}}$ \\
\hline Silene vulgaris & $10.12 \pm 1.18^{\mathrm{g}}$ & $0.31 \pm 0.05^{\mathrm{e}}$ & $0.71 \pm 0.05^{\mathrm{c}}$ & $0.51 \pm 0.00^{\mathrm{c}}$ & $11.65 \pm 1.29^{\mathrm{f}}$ \\
\hline \multicolumn{6}{|l|}{ Wild asparagus } \\
\hline Asparagus acutifolius & $1.89 \pm 0.03^{b c}$ & $0.07 \pm 0.03^{\mathrm{a}}$ & $0.78 \pm 0.05^{\mathrm{c}}$ & $0.03 \pm 0.00^{\mathrm{a}}$ & $2.78 \pm 0.05^{\mathrm{b}}$ \\
\hline Bryonia dioica & $0.75 \pm 0.06^{\mathrm{a}}$ & $0.13 \pm 0.00^{\mathrm{c}}$ & $0.66 \pm 0.00^{\mathrm{b}}$ & $0.06 \pm 0.00^{\mathrm{a}}$ & $1.57 \pm 0.14^{\mathrm{a}}$ \\
\hline Humulus lupulus & $4.51 \pm 0.46^{\mathrm{e}}$ & $0.24 \pm 0.02^{\mathrm{d}}$ & $8.98 \pm 0.03^{\mathrm{e}}$ & $0.69 \pm 0.01^{\mathrm{d}}$ & $14.32 \pm 0.55^{\mathrm{f}}$ \\
\hline Tamus communis & $1.36 \pm 0.05^{\mathrm{ab}}$ & $0.09 \pm 0.00^{\mathrm{b}}$ & $1.85 \pm 0.15^{\mathrm{d}}$ & $0.37 \pm 0.07^{\mathrm{b}}$ & $3.62 \pm 0.10^{\mathrm{d}}$ \\
\hline
\end{tabular}

n.d. $=$ non detected 
Table 3. Extraction yields (\%), total phenolics (mg GAE/g extract) and flavonoids ( $\mathrm{mg} \mathrm{CE} / \mathrm{g}$ extract) contents, and antioxidant activity (EC ${ }_{50}$ values; $\mathrm{mg} / \mathrm{ml})$ of the wild vegetables. Different letters mean significant differences in each column $(\mathrm{p}<0.05)$.

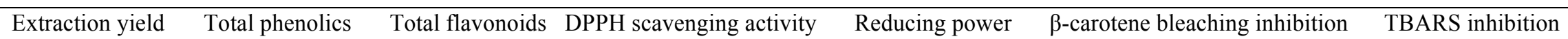

\begin{tabular}{|c|c|c|c|c|c|c|c|}
\hline \multicolumn{8}{|l|}{ Leafy vegetables } \\
\hline Apium nodiflorum & 19.59 & $80.47 \pm 4.41^{\mathrm{h}}$ & $45.48 \pm 1.61^{\mathrm{e}}$ & $0.07 \pm 0.00^{\mathrm{a}}$ & $0.02 \pm 0.00^{\mathrm{a}}$ & $0.02 \pm 0.00^{\mathrm{a}}$ & $0.04 \pm 0.00^{\mathrm{b}}$ \\
\hline Foeniculum vulgare & 29.67 & $42.16 \pm 0.98^{d}$ & $9.72 \pm 0.70^{\mathrm{b}}$ & $2.75 \pm 0.06^{\mathrm{c}}$ & $1.10 \pm 0.02^{\mathrm{e}}$ & $0.47 \pm 0.00^{\mathrm{b}}$ & $0.02 \pm 0.00^{\mathrm{a}}$ \\
\hline Montia fontana & 25.68 & $75.53 \pm 7.05^{\mathrm{g}}$ & $16.67 \pm 0.62^{\mathrm{c}}$ & $1.49 \pm 0.07^{\mathrm{b}}$ & $0.36 \pm 0.01^{\mathrm{b}}$ & $0.48 \pm 0.01^{\mathrm{b}}$ & $0.02 \pm 0.00^{\mathrm{a}}$ \\
\hline Silene vulgaris & 15.98 & $26.72 \pm 1.63^{\mathrm{b}}$ & $21.65 \pm 5.53^{\mathrm{d}}$ & $3.31 \pm 0.07^{\mathrm{d}}$ & $0.84 \pm 0.01^{\mathrm{d}}$ & $0.62 \pm 0.08^{\mathrm{c}}$ & $0.02 \pm 0.00^{\mathrm{a}}$ \\
\hline \multicolumn{8}{|l|}{ Wild asparagus } \\
\hline Asparagus acutifolius & 46.14 & $17.60 \pm 0.29^{\mathrm{a}}$ & $6.09 \pm 0.27^{\mathrm{a}}$ & $4.87 \pm 0.38^{\mathrm{e}}$ & $1.62 \pm 0.00^{\mathrm{h}}$ & $0.47 \pm 0.04^{\mathrm{b}}$ & $0.07 \pm 0.02^{\mathrm{d}}$ \\
\hline Bryonia dioica & 22.01 & $35.10 \pm 2.43^{\mathrm{c}}$ & $16.31 \pm 0.70^{\mathrm{c}}$ & $4.43 \pm 1.29^{\mathrm{e}}$ & $1.44 \pm 0.01^{\mathrm{g}}$ & $0.47 \pm 0.03^{b}$ & $0.08 \pm 0.01^{\mathrm{d}}$ \\
\hline Humulus lupulus & 22.86 & $55.83 \pm 1.34^{\mathrm{f}}$ & $9.56 \pm 0.65^{\mathrm{b}}$ & $1.36 \pm 0.02^{\mathrm{b}}$ & $0.80 \pm 0.01^{\mathrm{c}}$ & $0.48 \pm 0.02^{b}$ & $0.03 \pm 0.00^{\mathrm{ab}}$ \\
\hline Tamus communis & 22.49 & $49.51 \pm 4.07^{\mathrm{e}}$ & $9.33 \pm 1.44^{\mathrm{b}}$ & $3.59 \pm 0.93^{\mathrm{d}}$ & $1.32 \pm 0.01^{\mathrm{f}}$ & $0.49 \pm 0.15^{b}$ & $0.05 \pm 0.01^{\mathrm{c}}$ \\
\hline
\end{tabular}


Table 4. Correlations coefficients ( $P$-values) between the analysed compounds and the antioxidant capacity of the studied wild vegetables. Significant correlations are showed in bold letter $(\mathrm{p}<0.05)$.

\begin{tabular}{|c|c|c|c|c|c|c|c|c|c|c|c|}
\hline & Phen & Flav & DPPH & $\mathrm{RP}$ & $\beta$-car & TBARS & $\alpha-T$ & $\beta-T$ & $\gamma-T$ & $\delta-\mathrm{T}$ & T.T \\
\hline Phen & 1 & $\begin{array}{c}0.48 \\
(0.01)\end{array}$ & $\begin{array}{l}-\mathbf{- 0 . 7 7} \\
(0.00)\end{array}$ & $\begin{array}{c}-\mathbf{- 0 . 8 0} \\
(0.00)\end{array}$ & $\begin{array}{c}-0.54 \\
(0.01)\end{array}$ & $\begin{array}{l}-0.52 \\
(0.01)\end{array}$ & $\begin{array}{c}0.41 \\
(0.04)\end{array}$ & $\begin{array}{c}0.58 \\
(0.00)\end{array}$ & $\begin{array}{c}0.08 \\
(0.69)\end{array}$ & $\begin{array}{c}0.59 \\
(0.00)\end{array}$ & $\begin{array}{c}0.48 \\
(0.02)\end{array}$ \\
\hline Flav & & 1 & $\begin{array}{l}-\mathbf{- 0 . 5 7} \\
(0.00)\end{array}$ & $\begin{array}{c}-0.76 \\
(0.00)\end{array}$ & $\begin{array}{c}-0.63 \\
(0.01)\end{array}$ & $\begin{array}{c}0.30 \\
(0.15)\end{array}$ & $\begin{array}{c}0.31 \\
(0.14)\end{array}$ & $\begin{array}{c}0.01 \\
(0.98)\end{array}$ & $\begin{array}{c}0.48 \\
(0.15)\end{array}$ & $\begin{array}{c}0.31 \\
(0.14)\end{array}$ & $\begin{array}{c}0.07 \\
(0.72)\end{array}$ \\
\hline DPPH & & & 1 & $\begin{array}{c}0.90 \\
(0.00)\end{array}$ & $\begin{array}{c}0.47 \\
(0.02)\end{array}$ & $\begin{array}{c}0.70 \\
(0.00)\end{array}$ & $\begin{array}{c}-0.59 \\
(0.00)\end{array}$ & $\begin{array}{c}-0.34 \\
(0.09)\end{array}$ & $\begin{array}{c}-0.28 \\
(0.17)\end{array}$ & $\begin{array}{c}0.34 \\
(0.10)\end{array}$ & $\begin{array}{l}-0.67 \\
(0.00)\end{array}$ \\
\hline RP & & & & 1 & $\begin{array}{c}0.47 \\
(0.02)\end{array}$ & $\begin{array}{c}0.70 \\
(0.00)\end{array}$ & $\begin{array}{c}-0.48 \\
(0.01)\end{array}$ & $\begin{array}{c}-0.46 \\
(0.02)\end{array}$ & $\begin{array}{c}0.01 \\
(0.95)\end{array}$ & $\begin{array}{c}-0.49 \\
(0.01)\end{array}$ & $\begin{array}{l}-0.47 \\
(0.02)\end{array}$ \\
\hline$\beta$-car & & & & & 1 & $\begin{array}{l}-0.07 \\
(0.75)\end{array}$ & $\begin{array}{c}-0.38 \\
(0.06)\end{array}$ & $\begin{array}{c}0.05 \\
(0.83)\end{array}$ & $\begin{array}{c}0.06 \\
(0.78)\end{array}$ & $\begin{array}{c}-0.47 \\
(0.02)\end{array}$ & $\begin{array}{c}-0.27 \\
(0.22)\end{array}$ \\
\hline TBARS & & & & & & 1 & $\begin{array}{c}-0.52 \\
(0.01)\end{array}$ & $\begin{array}{c}0.34 \\
(0.10)\end{array}$ & $\begin{array}{c}-0.27 \\
(0.19)\end{array}$ & $\begin{array}{c}-0.34 \\
(0.10)\end{array}$ & $\begin{array}{c}-0.60 \\
(0.02)\end{array}$ \\
\hline$\alpha-T$ & & & & & & & 1 & $\begin{array}{c}0.16 \\
(0.45)\end{array}$ & $\begin{array}{c}0.20 \\
(0.34)\end{array}$ & $\begin{array}{c}0.22 \\
(0.29)\end{array}$ & $\begin{array}{c}0.87 \\
(0.00)\end{array}$ \\
\hline$\beta-T$ & & & & & & & & 1 & $\begin{array}{c}-0.22 \\
(0.28)\end{array}$ & $\begin{array}{c}-0.11 \\
(0.58)\end{array}$ & $\begin{array}{c}21 \\
(0.32)\end{array}$ \\
\hline$\gamma-T$ & & & & & & & & & 1 & $\begin{array}{c}0.59 \\
(0.00)\end{array}$ & $\begin{array}{c}0.59 \\
(0.00)\end{array}$ \\
\hline$\delta-T$ & & & & & & & & & & 1 & $\begin{array}{c}\mathbf{0 . 4 5} \\
(\mathbf{0 . 0 3}) \\
1\end{array}$ \\
\hline
\end{tabular}

Phen: Phenolics; Flav: Flavonoids; DPPH: DPPH assay; RP: Reducing Power; $\beta$-car: $\beta$-carotene bleaching inhibition; TBARS: TBARS assay; $\alpha$-T: $\alpha$-Tocopherol; $\beta$-T: $\beta$-Tocopherol; $\gamma$-T: $\gamma$-Tocopherol; $\delta$-T: $\delta$-Tocopherol. 


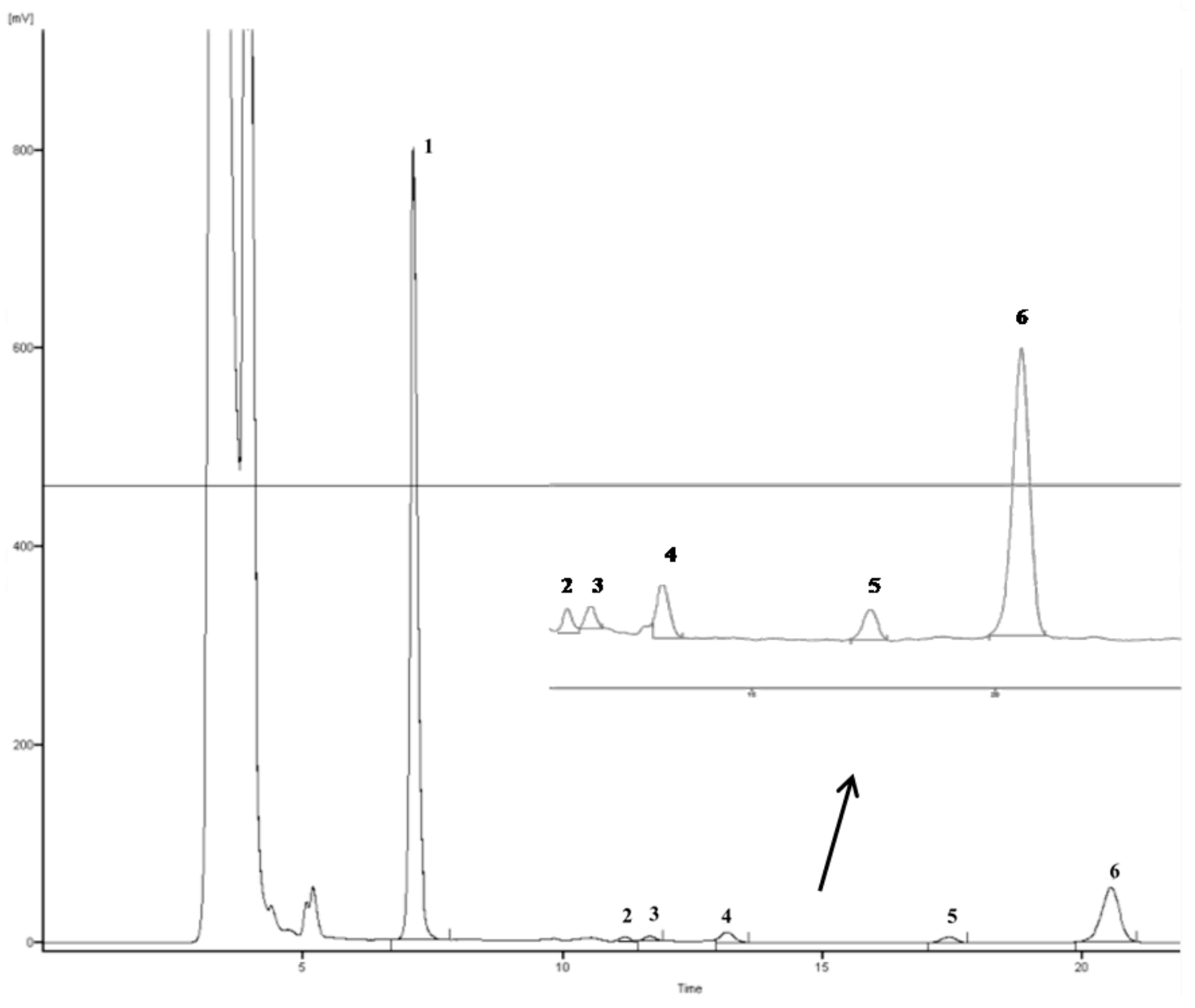

Figure 1. HPLC fluorescence chromatogram of Silene vulgaris. Peaks: (1) $\alpha$ tocopherol; (2) BHT (butylated hydroxytoluene); (3) $\beta$-tocopherol; (4) $\gamma$-tocopherol; (5) $\delta$ - tocopherol; (6) I.S. - internal standard (tocol). 
$2 a$.

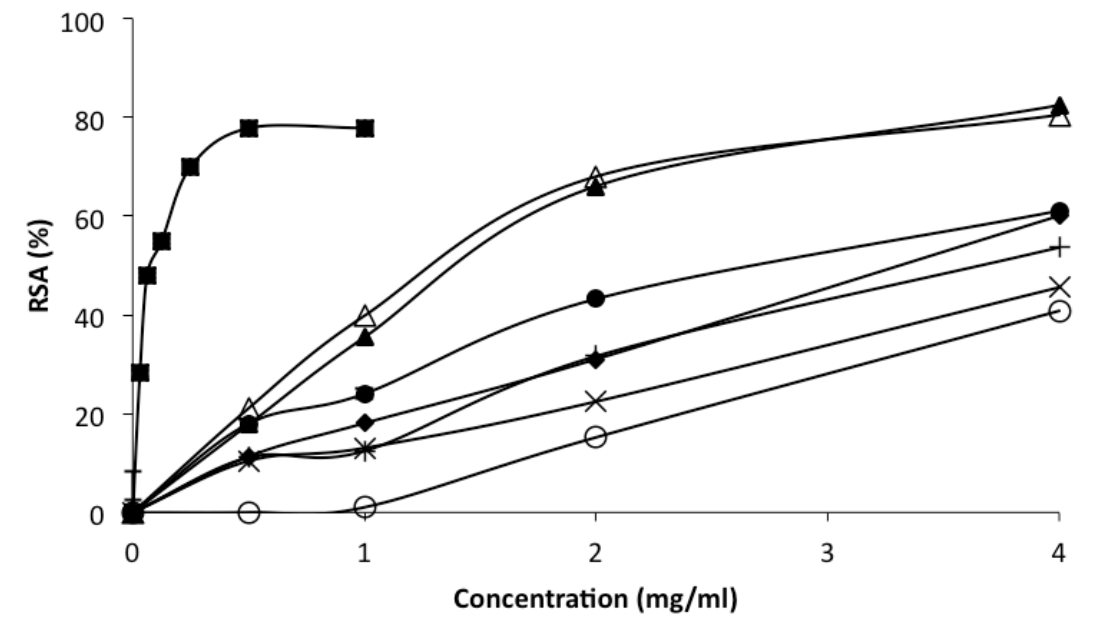

- Apium nodiflorum

- Asparragus acutifolius

$* \leftarrow$ Bryonia dioica

$\longrightarrow$ Foeniculum vulgare

$\triangle$ Humulus lupulus

$\longrightarrow$ Montia fontana

$\longrightarrow$ Silene vulgaris

$\longrightarrow$ Tamus communis

$2 b$.

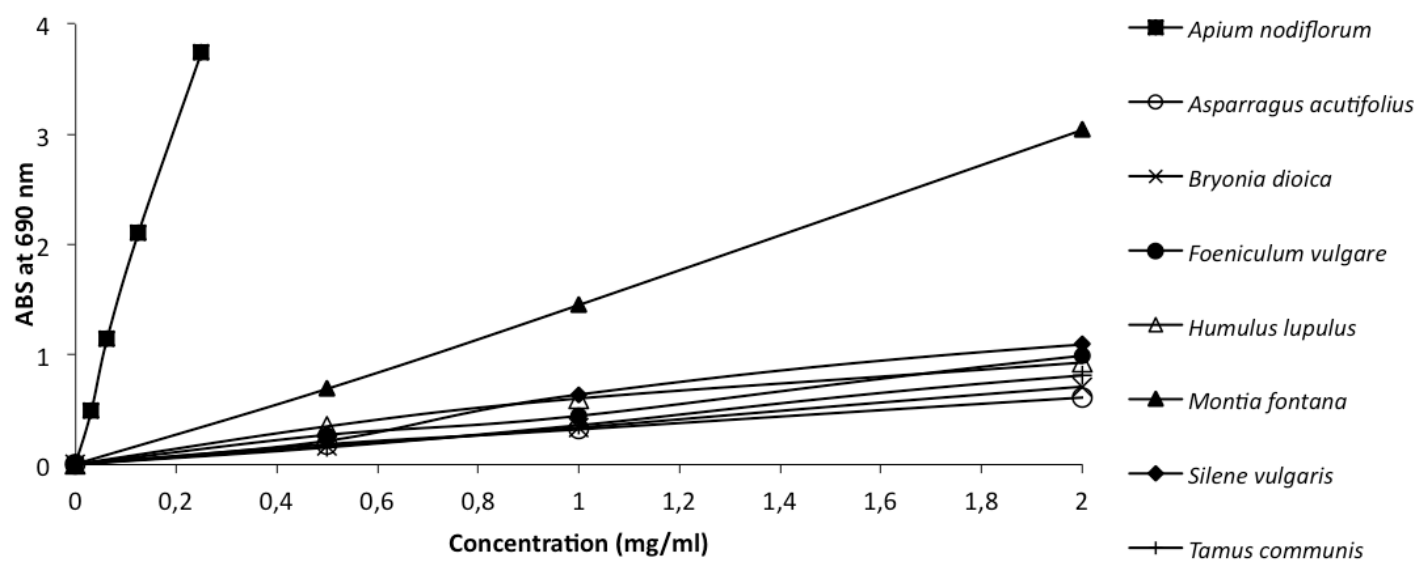


2c.

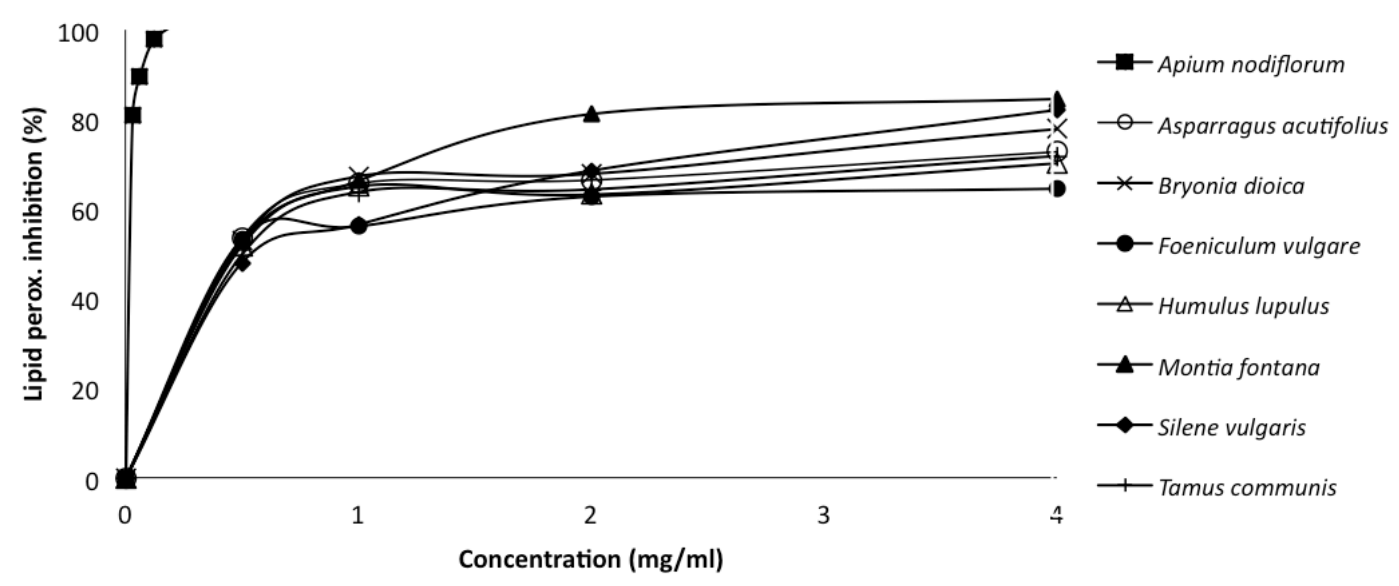

$2 d$.

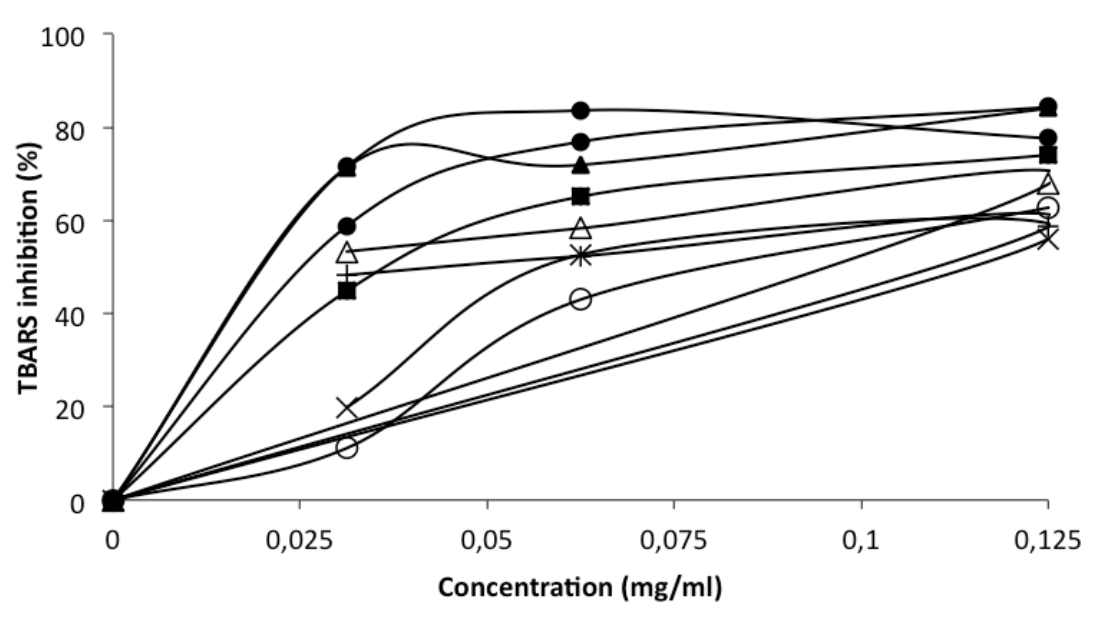

Apium nodiflorum

- Asparagus acutifolius

$\rightarrow$ Bryonia dioica

- Foeniculum vulgare

$\triangle$ Humulus lupulus

$\longrightarrow$ Montia fontana

Silene vulgaris

— Tamus communis

Figure 2. Antioxidant properties of the studied vegetables using different assays. a) Radical-scavenging activity on DPPH radicals, b) reducing power, c) $\beta$-carotene bleaching inhibition and d) TBARS formation inhibition. 